Mesned İlahiyat Araştırmaları Dergisi / The Journal of Mesned of Theological Studies ISSN 2667-7075| e-ISSN 2687-3605 | https://dergipark.org.tr/tr/pub/mesned

Cilt (Vol.) 12 Sayı (Issue 2) Güz - (Autumn) 2021

ARAŞTIRMA MAKALESI | RESEARCH ARTICLE

(Bu makalenin intihal içermediği benzerlik tarama programlarıyla teyit edilmiştir. / The similarity that this article does not contain plagiarism, has been confirmed by plagiarism checker programs.)

Doi: $10.51605 /$ mesned.929586

Gönderim Tarihi: 10.03.2021 Kabul Tarihi: 24.12.2021

\title{
Dilin Kökeni ve Teolojik Bağlamı
}

- The Origin of Language and Its Theological Context-

\section{Hulusi Arslan* \\ Numan Karagöz**}

Atıf/Citation: Arslan, Hulusi; Karagöz, Numan. "Dilin Kökeni ve Teolojik Bağlamı / The Origin of Language and Its Theological Context". Mesned İlahiyat Araștırmaları Dergisi / The Journal of Mesned of Theological Studies, (Güz 2021-2): 431-451.

Öz:

İlk insan toplulukları arasında dillerin nasıl oluștuğu düșünce tarihinde bir merak konusudur. Dillerin kökeni konusu felsefeciler, teologlar ve dilciler tarafından çağlar boyunca tartışılmıştır. Bu tartıșmalarda dilin kökeniyle ilgili farklı yaklașımlar değișik açılardan incelenmiștir. Bu çalıș-mamda İslam düșüncesinde dillerin kökeni hakkında farklı teoriler ve bu teorilerin teolojik bağ-lamlarını incelemeyi hedefliyorum. Dilin kökeni konusuyla özellikle kelâm ve usûl bilginlerinin il-gilendiği görülmektedir. Meselenin özünde ilk dilin kim tarafından olușturulduğu konusu yer al-maktadır. İnsan türünün atası kabul edilen Hz. Âdem'in konuştuğu dilin Allah tarafından öğretildi-ğini savunanlar olduğu gibi insanların kendi aralarında uzlașarak ilk dili meydana getirdiği de savunulmuştur. Kelâm'da dilin kökeni meselesi Allah'ın isim ve sıfatları, insanın sorumlu tutulması Kur'ân'ın yorumlanması konusuyla ilișkili olarak tartıșılmıștır. Yine bu konu Mu'tezile ve Ehl-i sünnet arasında șiddetli tartıșmalara sebep olan Kur'an'ın mahlûk olup olmadığı bağlamında da gündeme gelmiştir. İslam düşüncesinde dillerin kökenine ilişkin teorileri "zâtî/tabiî delâlet teori-si", "tevkîf teorisi”, "Muvâza'a teorisi", "tevakkuf teorisi” șeklinde sıralamak mümkündür.

Zâtî/tabiî delâdet teorisi Mu'tezile’den Abbâd b. Süleyman es-Saymerî’ye (ö. 250/864) nispet edilmektedir. Bu teoriye göre lafız ile mana arasında doğal bir ilișki vardır. Dolayısıyla belirli bir nesneye isim olan kelime nesne ile olan ilișkisinden dolayı ona isim olmuștur. İsimleri koyan (vâz'ı) ne Allah ne de insandır. İsimler söz konusu olduğunda ne Allah tarafından verili (tevkif) ne de insanlar arasındaki uzlașıya dayalı (Muvâza'a) bir durum söz konusudur. Ancak bu teori kelamcıların çoğu tarafından kabul görmemiştir.

* Prof. Dr., İnönü Üniversitesi İlahiyat Fakültesi, hulusi.arslan@inonu.edu.tr. Orcid: 00000003-3578-0775

* Dr. Öğr. Görevlisi, Harran Üniversitesi İlahiyat Fakültesi, numan_karagoz@hotmail.com Orcid: 0000-0002-1207-8070. 
Tevkîf teorisi Ehl-i sünnetten Ebü'l-Hasen el-Eş'arî (ö. 324/935-36), İbn Fâris (ö. 395/1004), İbn Fûrek (ö. 406/1015), Ebû İshâk el-İsferâyînî (ö. 418/1027), İbn Hazm (ö. 456/1064) ve İbn Teymiyye (ö. 728/1328) gibi âlimlere nispet edilmektedir. Eş'arîler'in geneline nispet edilen bu görüșe göre dil Allah tarafindan insana ya i- vahiy yoluyla ya ii- sesler yaratmak suretiyle ya da insanda zorunlu/apriori bilgi yaratarak öğretilmiş olabilir. Bu teorinin savunucularından biri olan İbn Teymiyye'ye göre dilin Allah tarafından verildiği (tevkif) konusunda icmâ bulunmaktadır. Ona gö-re Allah insana meramını ifade edeceği lafızları ilham etmiștir. İlk ilham da Hz. Âdem'e verilmisttir. Hatta bu ilham sadece insanlara değil hayvanlara da bahşedilmiştir. Bu teoriyi savunanlar "Allah Âdem'e bütün isimleri öğretmiștir." (Bakara, 2/31) "Rahmân Kur'an'ı öğretmis, insanı yaratmıs, ona açıklamayı öğretmiştir." (Rahmân, 55/1-4) gibi ayetlerden hareketle Kur'an'dan bazı deliller getirmişlerdir. Bu teoriyi savunanlar konuşma dilinin insanlar tarafından oluşması için çok uzun bir zaman gerektiğini bu sebeple de Allah'ın Hz. Âdem'e dili öğrettiğini söylemişlerdir.

Muvâza'a teorisi genelde Mu'tezile’ye özelde ise Ebu Hâşim'e (ö. 321/933) nispet edilir. Bu teoriye göre konuştuğu dili tarih içerisinde üreten bizzat insanın kendisidir. Allah insana akıl ve konuşma yeteneği vermiștir. İlk insanlar önce varlıkları tanımış sonra onlara işaret ederek bazı sesler çıkarmıș ardından o seslerin o varlığa ișaret ettiği üzerinde uzlașmıșlardır. İnsanların konuștuğu dil bu şekilde tarihi süreç içerisinde sesler ve manalar üzerinde insanların uzlaşmasıyla oluşmuştur. Bu teoriyi savunanlara göre Allah'ın insanlara vahiy göndermesi için önce insanların kendi aralarında konuștuğu bir dile sahip olmaları gerekir. Nitekim Kur'an'da “Biz her resulü kendi kavminin lisanıyla gönderdik..." (İbrahim: 14/4) denilmektedir. Bu da vahiy gönderilmeden önce insanların bir dile sahip olduklarını gösterir. Ayrıca dilin Allah tarafından öğretilmesi insanda zorunlu bilginin oluşmasını sağlar. İnsan varlı̆̆ın hakikatini zorunlu olarak bilirse sorumluluğunu da bu şekil-de bilecektir. Oysa insanın Allah'ı tanıması zorunlu bilgilere değil çıkarımsal (iktisâbî) düşünceye bağlidır.

Tevakkuf teorisi Bâkıllânî (ö. 403/1013) ile başlayıp devam eden Eş'arî çizgide benimsenen bir görüștür. Mutezile içinde de tevakkuf yaklașımını benimseyen veya kararsız kalanların bulunduğu belirtilmektedir. Tevakkuf teorisine göre dil Allah tarafından öğretilmiş olabileceği gibi insanlar tarafından da üretilmiş olabilir, her ikisi de mümkündür. En doğrusu bu konuda kararsız kalmaktır.

Dilin kökenine ilișkin bu teorilerin bazı teolojik bağlamları vardır. İlkin dilin kökeni meselesi Allah'a isim verme konusuyla ilgilidir. Dilin insanlar tarafından üretilebileceğine inanan Mútezile âlimleri akıl ve kıyas yoluyla Allah'a isim verilebileceğini savunmușlardır. Dilin kaynağını Allah'ın öğretimine dayandıran Ehl-i sünnet âlimleri ise şeriatın belirlediği isimlerin dışında Allah'a kıyas yoluyla isim vermeyi caiz görmemișlerdir. İkinci olarak dillerin kökeni meselesi insanın sorumluluğu (teklif) konusuyla ilişkilendirilmiştir. Mu'tezile âlimleri Allah'ın insana hitap etmesi için önce insanların konuştukları bir dilin bulunması gerektiğini savunmuşlardır. Üçüncü olarak dillerin kökeni meselesi halku'l-Kur'an ve te'vil konusuyla ilișkilendirilmiștir. Cünkü Kur'an insanların olușturduğu dil aracıllğıyla nazil olmuş ve sonradan yaratılmıştır. Bu durumda Kur'an'ın yorum-lanması imkân dâhilinde olacaktır. Özetle dilin kökenine ilișkin görüșler bazı teolojik yaklașımları destekler mahiyette ortaya konulmuştur.

Anahtar Kelimeler: Dilin Kökeni, Âdem'in Dili, Tevkîf, Muvâza'a/Uzlașım, Mu'tezile, Kâdî Abdülcebbâr.

\section{Summary:}

The issue of how languages came to be among the first human societies is a matter of curiosity in the history of thought. The origin of languages has been discussed by philosophers, theologians and lin-guists for ages. In these debates, different approaches to the origin of language have been examined from different perspectives. In this study, I aim to examine different theories about the origin of lan-guages in Islamic thought and the theological contexts of these theories. It is seen that the kalam and usûl scholars are particularly interested in the origin of the language. At the core of the issue is the issue of who created the first language. The issue of who created the first language takes place at the core of the issue in question. There are those who argue that the language that Adam -who considered the ancestor of the human species- spoke was taught by God, and it was also argued that people creat-ed the first language by coming to terms with each other. The issue of the 
origin of language in Kalam has been discussed especially in the context of the names and attributes of Allah, the responsibility of human, and the interpretation of the Qur'an. Again, this issue has also come to the fore in the context of whether the Qur'an is created or not, which caused fierce debates between the Mu'tazila and the ahl al-Sunna. It is possible to list the theories on the origin of languages in Islamic thought as "theory of substantive/natural signification", "theory of tawqîf", "theory of muwāda'a", and "theory of tawaqquf". The theory of substantive/natural signification generally attributed to Abbad b. Süleyman es-Saymerî (d. 250/864). According to this theory there is a natural relationship between word (lafz) and mean-ing (ma'nâ). Therefore, the word, which is a name for a particular object, has become a name for it due to its relationship with the object. It is neither God nor man who posits names. When it comes to names, there is neither a situation given by Allah (tawqîf) nor a situation based on consensus (muwāda'a) between people. However, this theory was not accepted by most theologians. The theory of tawqîf attributed to scholars like Ebü'l-Hasen alAsh'ari (d. 324/935-36), Ibn Faris (d. 395/1004), Ibn Fureq (d. 406/1015), Abu Ishaq al-İsferâyînî (d. 418/1027), Ibn Hazm (d. 456/1064) and Ibn Taymiyya (d. 728/1328) from ahl al-Sunna. According to Ibn Taymiyya, one of the defenders of this theory, there is consensus (al-ijmā') on the issue of language given by Allah (tawqîf). According to him, Allah inspired man with words to express his meaning. The first inspiration given to Adam. In fact, this inspiration is bestowed not only on humans but also on animals. The scholars who advocate this theory brought some proofs from the Qur'an based on verses such as "God taught Adam all the names." (Baqara, 2/31), "The Most Merciful taught the Qur'an, created man and taught him to explain." (Rahman, 55/1-4). Those who defend this theory believe that it takes a very long time for the spoken language to be formed by the people. They said that God taught Adam the language.

Theory of muwāda'a is generally attributed to Mu'tezila and specifically to Abu Hashim (d. 321/933). According to this theory, it is man himself who produces the language he speaks throughout history. God gave man the ability to reason and speak. The first people first recognized the beings, then made some sounds by pointing at them, and then they agreed that those voices should point to that being. The language spoken by people in this way was formed by the consensus of people on sounds and meanings in the historical process. According to those who support this theory, in order for God to send revelation to people, they must first have a language that people speak among themselves. As a matter of fact, it is said in the Qur'an, "We sent every messenger in the language of his people..." (Ibra-him: 14/4). This shows that people had a language before the revelation was sent. In addition, the teaching of language by Allah ensures the formation of necessary knowledge in human beings. If man necessarily knows the truth of existence, he will know his responsibility in this way. However, the recognition of God depends on inferential thinking, not on necessary knowledge.

The theory of tawaqquf is a view adopted in the Ash'arite line, which started with Bâqillani and con-tinued. It is stated that among the Mu'tezila there are those who adopt the approach of tawaqquf or remain undecided. According to the theory of tawaqquf, language can be taught by God or produced by humans, both are possible. The best thing to do is to remain undecided.

These theories of the origin of language have some theological context. First, the issue of the origin of language is related to the issue of naming God. Mu'tazila scholars, who believe that language can be produced by humans, argued that it is possible to give names to Allah through reason and analogy. The scholars of ahl as-Sunnah, who based the language on the teaching of Allah, did not consider it permis-sible to name Allah by analogy, except for the names determined by the Shari'ah. Secondly, the issue of the origin of languages is associated with the issue of human responsibility. Mu'tazila scholars have argued that in order for Allah to address human beings, there must first be a language that people speak. Thirdly, the issue of the origin of languages has been associated with whether the Qur'an is a creature or not and with the subject of interpretation of Qur'an (ta'will). Because the Qur'an was re-vealed through the language created by humans and was created by God later. In this case, the inter-pretation of the Qur'an will be possible. In summary, the views on the origin of language have been put forward in support of some theological approaches.

Keywords: The origin of Languages, the language of Adam, tawqîf, lingual consensus (muwāda'a), Mu'tazila, Al-Qadı Abd al-Jabbar. 
Dilin Kökeni ve Teolojik Bağlamı

\section{GİRIş}

Dilin kökeninin ne olduğu sorusu, her zaman insanların merakını celbeden bir konu olmuştur. İlk insanlar konuşuyorlar mıydı? Nasıl ve hangi dili konuşuyorlardı? Konuştukları dil/diller ile bugün konuştuğumuz dil/diller arasında bir bağlantı var mıdır? İlk dil nasıl ortaya çıktı? Bütün diller tek bir dilden mi türedi? Bunlara benzer pek çok soru, çok eski zamanlardan beri insanların gündeminde olmuştur. Bu sorular, efsanelere konu edilecek kadar eski sorulardır. ${ }^{1}$ Hatta Cassirer'e göre, "dilin kökeni ve tabiatını soran felsefî soru, esas itibariyle varlığın köken ve tabiatının ne olduğu sorusu kadar eskidir."²

Dilin kökeni hakkındaki soruların bilimsel değeri ve önemi tartışmalıdır. Çünkü konu kökenle ilgili olup, ilk dilin nasıl ortaya çıktığı sorusunu sormaktadır. Bilimin ise; kökenlerle ve ilk nedenlerle değil, ikincil nedenlerle ilgilendiği belirtilmiştir. ${ }^{3}$ Öte yandan Batı'da bilimin yöntemi deney ve gözlem olarak kabul edilmiş ve "dilin ortaya çıkışı gözlemlenebilir bir olgu" 4 olarak kabul edilmemiştir. Bu sebeple dilbilimciler bu konuyla ilgilenmekten vazgeçmişler, hatta Paris Dil Kurumu, 1866 yılında, dilin kökeni konusundaki tüm araştırmaları yasaklamıştır. ${ }^{5}$

Ancak dilbilimcilerin bu tutumu, konuyu felsefî ve metafizik anlamda önemsiz kılmaz. Zaten bilim ile felsefe veya metafizik arasındaki fark, bilimin gözlemlenebilir olguları betimlemeye çalışması, metafiziğin ise duyulur âlemin ötesine gitmek ve köklere inmek iddiasında bulunmasıdır. Dolayısıyla, dilin kökeni meselesi, metafizik ve teolojik açıdan üzerinde durmaya değer görülmüştür. Meseleye bu açıdan bakan ve konunun önem, değer ve aynı zamanda zorluğuna dikkat çeken Merian şöyle der: "Dilin kökeni, insan zihninin ortaya koyabildiği en büyük meseledir; filozoflar tarafından ele alınmaya ve hakkında hüküm verilmeye en lâyık konudur; lâkin aynı zamanda da çözülmesi en zor olanıdır." 6 Nitekim bu ehemmiyetine binaen, dilin kökeni konusu felsefeciler, ilâhiyatçılar ve dilciler tarafından çağlar boyunca tartışılmış, bilginler bu konu-

1 S. Atakan Altınörs, "Rousseau'nun Dilin Kökeni Meselesine Yaklaşımı”, Bilig Türk Dünyası Sosyal Bilimler Dergisi 4/63 (2012), 1-10.

2 Altınörs, "Rousseau'nun Dilin Kökeni Meselesine Yaklaşımı", 1-10.

3 Jean-Louis Dessalles - v.dğr., Dilin Kökenleri, çev. S. Atakan Altınörs (İstanbul: Bilge Kültür Sanat Yayınları: 2014), 11.

4 Dessalles - v.dğr., Dilin Kökenleri, 9.

5 Dessalles - v.dğr., Dilin Kökenleri, 11.

6 Altınörs, "Rousseau'nun Dilin Kökeni Meselesine Yaklaşımı”, 1-10. 
da pek çok faraziye ortaya atmış, bir takım deneylere girişmişlerdir. ${ }^{7}$ Eski Yunan'da Sokrat'tan önceki bilginler de bu konuyla ilgilenmişlerdir. ${ }^{8}$ Eflâtun'un ise bu konuda bir diyalogu bulunmaktadır. ${ }^{9}$ Bu konu aynı zamanda kutsal kitaplarda da geçmektedir. Konuyla ilgili Tevrat, İncil ve Kur'an-1 Kerim’de (bkz. Bakara, 2/31-33) bir takım bilgiler bulunmaktadır. ${ }^{10}$

Konuyla kelâm ve usûl bilginleri de ilgilenmiştir. Özellikle ilk dilin kim tarafından vaz' edildiği tartışılmıştır. İlk dilin, Allah tarafından insana öğretildiğini (tevkîf) savunanlar olduğu gibi, insanların kendi aralarında uzlaşarak (Muvâza'a) ilk dili meydana getirdiği de savunulmuştur. Bu tartışmanın, ekollerin fıkıh ve kelâm usûlleriyle yakından ilişkisi bulunmaktadır. ${ }^{11}$

Kelâmda dilin kökeni konusunu tevhit, teklîf ve kelâmullah meselesi ile ilişkilendirmek mümkündür. ${ }^{12}$ Özellikle bazı kelâmcılar, konuyu Allah'ın isimlerinin tevkîfîliği-kıyâsîliği bağlamında ele almışlardır. ${ }^{13}$ Mu'tezile ve Ehl-i sün-

7 Faruk Bozgöz, "Dil-Toplum İlişkisi ve Ari-Sami Polemiğinde Dil ve Sami Dilleri”, Ekev Akademi Dergisi Yaz/20 (2004), 13.

8 Bernard G. Weiss, “Ortaçağ İslâm Âlimlerinin Dilin Menşei ile İlgili Tartışmaları”, çev. Adem Y1 ̆̆ın 2/25 (2003), 127-135.

9 Platon, Kratylos" Diyaloglar, çev. Teoman Aktürel (İstanbul: Remzi Kitabevi, 1983).

10 Hidayet Aydar - İsmail Ulutaş, "Kur'an-1 Kerim Ve Diğer Kutsal Kitaplara Göre Dil Olgusu”, Turkish Studies 5/4 (2010), 679-696.

11 Muhammed Âbid el-Câbirî, Binyetü'l-akli'l-Arabî (Beyrut: Merkez dirâsât el-vahde el-Arabiyye, 2009), 42

12 Mesela dilin Allah tarafından öğretilmiş olması (tevkîf), Allah ile insan arasında karşılıklı işaretleşme gibi bir takım sorunlar ortaya çıkartmaktadır ki bu gibi hususlar tevhit ve tenzih ilkelerine aykırıdır. Diğer taraftan Mutezile'ye göre Allah'ın kelâmının ezelî olmaması nedeniyle dilin Allah tarafından değil de, kulların kendi uzlaşıları yoluyla ortaya çıkartılmış olması, Mutezilî yaklaşıma daha uygun düşmektedir. Bu konuda geniş bilgi için bkz.: Nasr Hâmid Ebû Zeyd, el-Itticâh el-aklî fi't-tefsîr: Dirâse fî kaziyye el-mecâz fi'l-Kur'ân inde'lMu'tezile (Beyrut: el-Merkez es-sekâfî el-Arabî, 1996), 70-83.

13 Mesela Eş'arî kelâmcı İbn Fûrek (ö. 406/1015), bu iki konuyu aynı başlık altında ele almakta ve İmam Eş'arî'ye göre hem dillerinin aslının, hem de Allah'ın isimlerinin tevkîfî olduğunu söylemektedir (İbn Fûrek, Mücerredü Makâlâti'ş-Şeyh Ebi'l-Hasan el-Eş 'arî (Beyrut: Dâru'1Meşrik, 1987), 42.). Mâtürîdî kelâmcı Ebü'l-Yüsr el-Pezdevî (ö. 493/1100) ise, “Dillerin Aslı” başlığı altında, Ehl-i sünnet ve Mu'tezile'ye göre dillerin aslını izah ettikten sonra, Allah'ın isimleri de Ehl-i sünnet'e göre tevkîfîdir, demektedir (Ebü'l-Yüsr Muhammed el-Pezdevî, Usûlü'd-dîn, thk. Hans Peter Linss (Kahire: el-Mektebetü'l-Ezheriyye li't-Türâs, 2003), 226.). Ancak bu iki konu arasındaki en açık ilişkilendirme Mu'tezile kelâmcısı Kâdî Abdülcebbâr'da (ö. 415/1025) görülmektedir. Kâdî, el-Muğn̂̂ fî ebvâbi't-tevhîd ve'l-adl adlı eserinin beşinci cildinde, "Allah'ın İsim ve Sıfatları" ile alâkalı konulara değinir. Burada öncelikle "Diller Üzerine Muvâza'a” ve devamındaki birkaç başlık altında, dilin kökenine dair görüşlerini açıklar. Eşyaya isim vermenin insanların gücü ve imkânları dairesinde olduğu, insanların 
net arasında şiddetli tartışmalara sebep olan Kur'an'ın mahlûk olup olmadığı ve Allah'ın isimlerinin tevkîfî mi, kıyâsî mi olduğu tartışmaları, dilin kökeni konusuyla yakından ilişkilendirilmektedir. ${ }^{14}$

Dilin kökeni konusunda bazı çağdaş çalışmalar bulunmaktadır. ${ }^{15}$ Bu çalışmalarda, dilin kökeniyle ilgili farklı yaklaşımlar değişik açılardan incelenmiştir. Bizim çalışmamızda ise İslam düşüncesinde dillerin kökeni hakkında farklı teorilerin bir arada tanıtımı ve incelenmesi hedeflenmiştir. Bunun yanında bazı hatalı tespitlerin düzeltilmesi düşünülmüştür. ${ }^{16}$ İslam düşüncesinde dillerin

eşyayı isimlendirmesinin "hasen" olduğu, bunun için bir vahiy (sem') ve ilâhî bildirime (tevkîf) ihtiyaç bulunmadığı ve insanların ilk dili kendi aralarında uzlaşarak (Muvâza'a) oluşturduğu tezini savunur. Ardından aynı şeyin Allah'ın isimleri için de geçerli olduğunu söyler. Görüldüğü üzere Kâdî, eşyayı isimlendirmek ile Allah'ı isimlendirmek konularını açıkça birbiriyle ilişkilendirmekte ve "ilâhî isimlerin kaynağıyla ilgili tartışmaları, dilin kökeni tartışmalarına bağlamaktadır (Orhan Şener Koloğlu, Cübbâiler'in Kelâm Sistemi (İstanbul: TDV İSAM Yayınları, 2011), 310.).

14 Ebû Zeyd, el-İtticâh el-aklî, 74.

15 Örnek olarak bkz: Altınörs, "Rousseau'nun Dilin Kökeni Meselesine Yaklaşımı”; Aydar Ulutaş, "Kur'an-1 Kerim Ve Diğer Kutsal Kitaplara Göre Dil Olgusu"; Weiss, "Ortaçă̆ İslâm Âlimlerinin Dilin Menşei ile İlgili Tartışmaları"; Zeki Yıldırım, "Kur'ân Işı̆̆ında Dillerin kaynağı Problemi", Atatürk Üniversitesi İlâhiyat Fakültesi Dergisi 22 (2004), 88-107.

16 Konumuza en yakın çalışma olarak Ebu Zeyd, Mu'tezile'nin mecaz anlayışını ele aldığı söz konusu eserinin birinci bölümünde, Muvâza'a konusunu Bâkıllânî ve Kâdî Abdülcebbâr'ın görüşlerini mukayese etmek suretiyle vermektedir. Ancak Ebu Zeyd'in meseleyi daha çok 'kelâmullah' bağlamında ele aldığını ve yorumlarını da o çerçevede yaptığını zikretmek gerekir. Biz ise, konuyu ilk dile dair kelamcıların farklı yaklaşımlarının mukayesesi ve Kâdî Abdülcebbâr'ın yaklaşımı çerçevesinde ele aldık ve hem Bâkıllânî, hem de diğer Eş'arî, Mâturîdî ve Selefî yaklaşımlara sahip kelâmcılarla mukayese ederek, daha geniş bir yelpaze sunduk. Yine Ebu Zeyd'den farklı birtakım sonuçlara da ulaştık. Mesela Ebu Zeyd tevkîf görüşünü Eş'arîler'e, Muvâza'a görüşünü ise Mu'tezile'ye genel olarak isnat etmektedir. Biz bunun doğru olmadığını: Eş'arîlerin içinde tevkîf görüşünü benimsemeyenlerin bulunduğunu hatta tevkîf görüşünün bizzat Eş'arî tarafından bile ne derece savunulduğunun kesin olarak bilinmediğini tespit ettik. Aynı şekilde Muvâza'a görüşünün de Mu'tezile içinde mutlak bir kabul görmediğini Mu'tezilî kaynaklara referansla belirttik. Başka bir örnek olarak Ebu Zeyd'in "ta'lîm-i esmâ" ayetiyle ilgili yorumlarını verebiliriz. Ebu Zeyd bu ayetin Mu'tezile'yi zora soktuğunu ve Mu'tezile'nin buna cevap vermekte zorlandığını ifade etmektedir. Ancak biz, yaptığımız mukayeseli çalışma sonucunda gördük ki Eş'arîler bile bu ayetin tevkîfe kesin delâlet etmeyeceği konusunda görüş belirtmektedirler. Dolay1sıyla, bu ayetin $\mathrm{Mu}^{\prime}$ tezilî yaklaşımı zora sokacağı iddiası bizce dayanaksız görünmektedir. Sonuç olarak, dilin kökeni konusunda son dönemde çok sayıda çalışma yapıldığı, ancak özellikle Mu'tezilî yaklaşım konusunda yapılan bu çalışmaların yetersiz olduğu gözlemlenmiş ve bu konuda Kâdî Abdülcebbâr özelinde monografik bir çalışma yapmanın faydalı olacağı mülâhazasıyla bu çalışma meydana getirilmiştir. 
kökenine ilişkin teorileri, "zâtî/tabiî delâlet teorisi", "tevkîf teorisi", "Muvâza'a teorisi", "tevakkuf teorisi" şeklinde sıralamak mümkündür. Çalışmada görüşlerin tespitinde betimleyici yönteme, değerlendirmesinde veri analizi ve karşılaştırma yöntemine başvurulmuştur.

\section{DİLLERIN KÖKENINE İLISSTIN TEORILER}

\subsection{Zâtî/Tabiî Delâlet Teorisi}

Dillerin kökenine ilişkin farklı görüşleri "dilin vâzı'ı" başlığı altında tartışan Fahreddîn er-Râzî (ö. 606/1210) bu görüşlerin hepsinin de mümkün olduğunu, muhakkiklerin bu konuda tevakkuf ettiğini belirtir. Ancak bunlar arasından bir görüşü istisna eder ve bu görüşün fâsit olduğunu iddia eder ki; bu görüş Mu'tezile'den Abbâd b. Süleyman es-Saymerî'ye (ö. 250/864) aittir. Abbâd'a göre, lafız ile mana arasında tabii bir münasebet vardır ve lafız manaya kendi zatiyla delalet eder. ${ }^{17}$

Görüldüğü gibi Abbâd'ın görüşünün iki yönü vardır: a) Lafız ile mana, başka bir ifade ile isim ve müsemmâ arasında doğal bir ilişki vardır. Dolayısıyla nesneye isim olan kelime, nesne ile olan ilişkisinden dolayı ona isim olmuştur.

b) Lafız, herhangi bir vaz' ediciye gerek olmadan, kendi zatıyla medlûlü göstermektedir. ${ }^{18}$ Bu teoriye göre, isimleri koyan (vâz'1) ne Allah ne de kullarıdır. Dolayısıyla isimler söz konusu olduğunda ne Allah tarafından verili (tevkif) ne de insanlar arasında uzlaşıya dayalı (Muvâza'a) bir durum söz konusudur.

Tâceddin es-Sübkî (ö. 771/1370), lafız ile mana arasında tabii bir ilişki bulunduğu ve bu tabii ilişkiden ötürü lafzın müsemmâya isim yapıldığı fikrini reddeder. Ona göre, her zaman lafız ile mana arasında bir münasebet olmaz. Özellikle zıt anlamlı (birbirine zıt iki anlam taşıyan) kelimelerde bu durum açıkça görülür. Eğer lafız ile mana arasında bir münasebet varsa, bir kelime birbirine zıt iki anlamda nasıl kullanılır? Ayrıca bazı kelimeler zaman içinde anlam kaymalarına uğramaktadır. Lafız ile mana arasında tabii bir ilişki olsay-

17 Fahreddîn Muhammed b. Ömer b. el-Hüseyn er-Râzî, el-Mahsûl fí ilmi usûli'l-fikh (Y.y.: Müessesetü'r-risâle nâşirûn, tsz.), 1/181; Seyfüddîn el-Âmidî, el-Ịhkâm fî ușûli'l-ahkâm (Beyrut, ts.), 1/181; Celâleddin es-Süyûtî, el-Müzhir (Kahire: Dâru ihyâi'l-kütübi'l-Arabiyye, tsz.), 1/16; Fahreddîn Muhammed b. Ömer b. el-Hüseyn er-Râzî, el-Mahsûl fì ilmi usûli'l-fikh (Y.y.: Müessesetü'r-risâle nâşirûn, tsz.), 1/181; Seyfüddîn el-Âmidî, el-ịhkâm fì ușûli 'l-ahkâm (Beyrut, ts.), 1/181.

18 Abdülvehhâb b. Ali Taceddîn Sübkî - Ali b. Abdülkâfî Şeyhülislam Sübkî, el-İbhâc fî şerhi'lminhâc (Dubai: Dârü'l-buhûs li'd-dirâsati'l-islâmiyye, 2004), 3/24. 
dı, bu ilişkinin zaman içinde değişmemesi ve dolayısıyla, kelimenin anlamının sabit kalması gerekirdi. Dolayısıyla Abbâd'ın bu görüşü kabul edilemez. ${ }^{19}$

Abbâd'ın, lafzın kendi zatıyla manaya delalet ettiği yönündeki iddiasını Râzî şöyle reddeder: "Eğer kelimeler kendi zatlarıyla manalara delalet etseydi, herkesin her dili anlaması gerekirdi. Böyle bir durum olmadığına göre bu görüş batıldır." 20

Abbâd' b. Süleyman'a göre, lafız ile mana arasında tabii bir ilişki yoksa ve lafız manaya kendiliğinden delalet etmiyorsa, bu durumda muayyen bir lafzın muayyen bir manaya delaleti nasıl olur? Buradaki tercih neye göre yapılmaktadır? Ortada bir tercih sebebi olmadığına göre "tercih bilâ müreccih" kabul edilecektir ki bu, batıldır. Abbâd şöyle der: "Şayet lafızlar kendi zatlarıyla manaya delalet etmeseydi, "tercih bilâ müreccih" olurdu." 21

Ancak Râzî, bu gerekçeyi kabul etmez ve Abbâd'ın ileri sürdüğü "tercih bilâ müreccih" itirazını, dilin vâzı'ının Allah veya insanlar olması ihtimallerine göre iki şekilde cevaplandırır: Birinci ihtimale göre, (dili vaz' eden Allah ise) Allah âlemin yaratılmasını vakitler arasında bir vakte tahsis ettiği gibi, lafızları da manalara tahsis eder. İkinci ihtimale göre (dilin vâzı'ı insanlar ise) insanların, kelimeleri kullandıkları anda akıllarına tek seçenek gelmiş ve buna göre dili vaz' etmiş olabilirler."22 Böylece Râzî, lafzın manaya bir irade ve ihtiyar ile tahsis edildiğini ve bu konuda bir açmaz olmadığını savunur.

Sonuç olarak, dilin vaz'î bir olgu olduğu görüşü bazı istisnalar dışında kelâmcılar tarafından ortak kabul görmüş ve bu konudaki eleştiriler gerek Mu'tezile ve gerekse Eş'arî kelâmcılar tarafından cevaplandırılmıştır. Ancak dilin vâzı'ının kim olduğu hususunda ihtilaf edilmiştir. Ehl-i sünnet ulemasının çoğunluğunun tercihi dilin kökenin tevkîfî olduğu yönündedir.

1 Sübkî, el-íbhâc fì şerhi'l-minhâc, 3/25.

er-Râzî, el-Mahsûl, 1/181.

Sübkî, el-İbhâc fì şerhi'l-minhâc, 3/25.

er-Râzî, el-Mahsûl, 1/182. 


\subsection{Tevkîf Teorisi}

Sözlükte "birine bir şeyi açıklamak", "birini bir şeye vâkıf ve muttali kılmak" 23 anlamına gelir. Dilin tevkîf veya tevkîfî olması ise; "Allah'ın, kullarına dili öğretmesi"24 şeklinde sözlük manasına uygun olarak kullanılmaktadır.

Bu görüşün temsilcileri arasında Ebü'l-Hasen el-Eş'arî (ö. 324/935-36), İbn Fâris (ö. 395/1004), İbn Fûrek (ö. 406/1015), Ebû İshâk el-İsferâyînî (ö. 418/1027), İbn Hazm (ö. 456/1064) ve İbn Teymiyye (ö. 728/1328) gibi âlimler sayılabilir.

İbn Fûrek'in nakline göre, Eş'arî, dillerin asıllarının Allah'ın tevkîf ve talimiyle olduğunu, fürû'unun ise kıyas ve içtihat ile bu asıllardan türetilmiş olabileceğini söyler. ${ }^{25}$ Eş'arîler, dilin Allah tarafından kula ya vahiyle; ya sesler yaratarak; ya da kulda yaratılan zorunlu/apriori bilgi yollarıla öğretilebileceğini öne sürerler.. ${ }^{26}$ Meselâ Cüveynî (ö. 478/1085) tevkîfi "Allah'ın göğüslerde yaratacağı bedîhî ilim" ile izah eder. ${ }^{27}$ Râzî (ö. 606/1210) de benzer şekilde "Allah'ın birtakım manalar için bazı lafızlar yaratması ve bu lafızların bu manalar için yaratıldığına dair insanlarda zorunlu ilim yaratması" 28 şeklinde açıklar. Gazâlî; (ö. 505/1111) "Allah, bir kişi veya bir grubun duyacağ şekilde sesler ve harfler yaratır. O kişilerde, bu seslerin bir takım müsemmâlara delalet etmek üzere kastedildiği bilgisini yaratır. Kudret-i ezeliye bundan aciz değildir"29 diyerek tevkîfin imkânını açıklamaya çalışır. İbn Fâris (ö. 395/1004) ise; "dilin bir defada ve bir anda (topluca) indirilmediğini, Hz. Âdem'den itibaren her peygambere zamanında ihtiyaç duyduğu bilgilerin verildiğini ve en son $\mathrm{Hz}$. Muhammed (s.a.v.) ile dilin tamamlandığını" ifade eder. İbn Fâris Hz. Peygamber-

23 Mecme'u'l-lûga el-Arabiyye, el-Mu'cemü'l-vasît (Mısır: Mektebetü'ş-şurûk ed-devliyye, 2004), 1051.

24 İbn Fûrek, Mücerred, 42.

25 İbn Fûrek, Mücerred, 42.

26 Cemâleddîn Ebû Amr Osman b. Ömer b. Ebû Bekir İbn Hâcib, Muhtasar müntehâ es-su'l ve'l-emel fî ilmeyi'l-usûl ve'l-cedel (Beyrut: Dâr İbn Hazm, 2006), 1/269.

27 İmâmü'l-Haremeyn Ebü'l-Meâlî Abdülmelik b. Abdullah b. Yusuf el-Cüveynî, el-Burhân fî usîli'lfikh (Katar: Şeyh Halîfe b. Hamad Âl-Sânî, 1978), 1/170.

28 Abdurrahman Celâleddîn es-Suyûtî, el-Müzhir fì ulûmi’l-lûga ve envâ'ihâ (Beyrut: Menşûrâtü'lmektebeti'l-asriyye, 1986), 1/17.

29 Ebû Hâmid Muhammed b. Muhammed b. Muhammed b. Ahmed Gazâlî, el-Mustasfâ min ilmi'l-usûl (Medine: Şirketü'l-Medîneti'l-Münevvere li’t-tıbâa, tsz.), 3/8. 
den sonra ortaya yeni bir dilin (dilde yeniliklerin) çıktığına dair bir bilginin bulunmadığını ekler. ${ }^{30}$

İbn Fâris'in tevkîf anlayışına göre insanoğlunun dilin oluşumunda bir katkısı yoktur. Dil tamamıyla Allah tarafından peygamberler aracılığıyla insanlara öğretilir. İnsanlar bu öğretileri hiçbir değişikliğe uğratmadan ve geliştirmeden aynen kullanırlar. İbn Fâris, "Yakın dönemde Arapların herhangi bir kelime üzerinde muvazaa ettiklerine dair bir bilgi bize ulaşmadı. Hatta Sahabe'nin -belagat ve fesahat sahibi oldukları halde- herhangi bir dil veya yeni bir kelime icat ettiklerini bilmiyoruz" diyerek dilin tamamen tevkîfî olduğunda israr eder. ${ }^{31}$

Dilin tevkîfîliğini savunanlardan birisi de İbn Teymiyye'dir (ö. 728/1328). Ona göre dilde tevkîf konusunda bir icmâ bulunmaktadır. İlk defa Ebû Hâşim el-Cübbâî’nin (ö. 321/933) bu husustaki icmaya aykırı görüş belirttiğini ifade eden İbn Teymiyye'ye göre ${ }^{32}$ Allah insan türüne meramını ifade edeceği lafızlarr ilham etmiştir. İlk ilham da Hz. Âdem'e yapılmıştır. ${ }^{33}$ Hatta bu ilham sadece insanlara değil hayvanlara da yapılmıştır. Hayvanlar kendilerine yapılan bu ilham sayesinde birtakım sesler çıarmak suretiyle birbirlerinin muradını anlamaktadırlar. ${ }^{34}$

\subsubsection{Tevkîf Yaklaşımını Savunanların Kullandı̆̆ı Argümanlar}

Dilin kökeninin tevkîfî olduğunu savunanlar, iddialarını kanıtlamak üzere birtakım naklî ve aklî deliller kullanırlar. Naklî delil olarak en çok kullanılan ayetler şunlardır: ${ }^{35}$

“Allah Âdem'e bütün isimleri, öğretti. Sonra onlarn önce meleklere arz edip: Ĕ̆er siz sözünüzde sadık iseniz, şunların isimlerini bana bildirin, dedi." (Bakara, 2/31)

30 Ebü'l-Hüseyn Ahmed b. Fâris b. Zekeriyya İbn Fâris, es-Sâhibî fî fikhi'l-lûgati'l-Arabiyyeti ve mesâilihâ ve süneni'l-Arabi fî kelâmihâ (Beyrut: Dârü'l-kütübi'l-ilmiyye, 1997), 14.

31 İbn Fâris, es-Sâhibî fî fikhi'l-lûgati'l-Arabiyyeti ve mesâilihâ ve süneni'l-Arabi fì kelâmihâ, 14.

32 Ahmed b. Abdülhalîm el-Harrânî İbn Teymiyye, Mecmû́ u fetâvâ Şeyhülislâm İbn Teymiyye (Medine: Mucemme'u'l-melik Fehd, 2004), 7/90.

33 İbn Teymiyye, Mecmû'u fetâvâ, 7/95.

34 İbn Teymiyye, Mecmû'u fetâvâ Şeyhülislâm İbn Teymiyye, 7/91.

35 Bkz. Ali b. Muhammed el-Âmidî, el-İhkâm fî Usûli'l-Ahkâm (Riyad: Dâru's-Samîî, 2003), 1/1-102; er-Râzî, el-Mahsûl, 1/184-186; Yıldırım, “Kur'ân Işı̆̆ında Dillerin kaynağı Problemi” 146. 
“O'nun delillerinden biri de, gökleri ve yeri yaratmasl, lisanlarınızn ve renklerinizin değişik olmasıdır. Şüphesiz bunda bilenler için (alınacak) dersler vardır." (R̂िm, 30/22)

"Bunlar (putlar), sizin ve atalarınızın taktığı isimlerden başka bir şey değildir. Allah onlar hakkında hiçbir delil indirmemiştir. Onlar ancak zanna ve nefislerinin arzusuna uyuyorlar. Hâlbuki kendilerine Rableri tarafindan yol gösterici gelmiştir." (Necm, 53/23)

"Rahmân Kur'an'ı öğretti. İnsanı yarattı. Ona açıklamayı öğretti." (Rahmân, 55/1-4)

"Yaratan Rabbinin adıyla oku! O, insanı bir aşılanmış yumurtadan yarattı. Oku! İnsana bilmediklerini belleten, kalemle (yazmayl) öğreten Rabbin, en büyük kerem sahibidir." (Alak, 96/1-5)

Aklî delillere gelince; Eş'arî'ye göre, eğer dillerin aslı uzlaşma/Muvâza'a olsaydı, bu uzlaşma da başka bir uzlaşmaya muhtaç olurdu. Çünkü insanların bir söz veya ifade üzerinde konuşup anlaşabilmeleri için, öncesinde konuşup anlaştıkları sözler bulunmalıdır. Dolayısıyla diyalogun sağlanabilmesi için gereken bu sözler "tevkîf ile değil de yine uzlaşma ile elde edilmiştir" denirse, bu uzlaşma da tıpkı öncesindeki gibi başka bir uzlaşmaya ihtiyaç duyacak ve bu silsile sonsuza kadar gidecektir. Hâlbuki teselsül batıldır, dolayısıyla dillerin aslının uzlaşma olması da mümkün değildir. ${ }^{36}$ Benzer bir yaklaşımı savunan Ebû İshâk el-İsferâyînî’ye (ö. 418/1027) göre, insanların birbirini dil vaz' etmeye çağırabilmesi (yani konuşmanın başlayabilmesi) için gereken miktarı Allah tevkîf/talim etmiştir. Bundan sonrası hem tevkîf hem de Muvâza'a olabilir. ${ }^{37}$ Ebu İshâk bu görüşünü desteklemek için Eş'arî gibi teselsül delilini kullanır. ${ }^{38}$ Ebû İshâk'ın, Eş'arî'den farklı olarak, dilin bütünüyle tevkîfî olduğunu savunmadığı, ancak başlangıçta ilahi talimin şart olduğunu öne sürdüğü görülmektedir.

Tevkîf ile ilgili öne sürülen aklî delillerden birisi de İbn Hazm'a (ö. 456/1064) aittir. İbn Hazm'a göre dili uzlaşma ile meydana getirecek olan insanların aklî ve zihnî melekeleri gelişmiş, bilgi seviyeleri yüksek olmalıdır. İnsanın

36 İbn Fûrek, Mücerred, 42.

37 Şerefü'l-İslâm Ebü'l-Feth Ahmed b. Ali b. Berhân el-Bağdâdî İbn Berhân, el-Vusûl ile 'l-usûl (Riyad: Mektebetü'l-meârif, 1983), 1/121.

38 İbn Berhân, el-Vusûl ile'l-usûl, 1/122. 
bu seviyeye gelmesi de çok uzun zaman alır. ${ }^{39}$ Hâlbuki insanın kelâmsız olarak varlığını sürdürmesi mümkün değildir. Bu durumda ona dili birinin öğretmiş olması gerekir ki bu da Allah'tır. ${ }^{40}$ İbn Hazm'a göre ilk insanın bir dil oluşturabilecek entelektüel seviyeye sahip olmaması ve dil olmadan varlığını sürdüremeyeceği gerçekleri birlikte düşünülünce bu durum insanın Allah tarafından yaratıldığının ve nübüvvet kurumunun da bir delili olmaktadır. ${ }^{41}$

Dilin tevkîf olduğunu kanıtlamak üzere ileri sürülen başka bir aklî delile göre, dilin tevkîf değil de insanların bir araya gelip oluşturdukları bir sistem olduğu kabul edildiği takdirde vahiy müessesesi şüphe altına girer ve şeriata karşı güven sarsılır. Çünkü insanların uzlaşmasıyla oluşturulan dilde her zaman için değişmeler söz konusudur. Allah'ın vahyini indirdiği dil de değişmiş olabilir. Böylece Allah'ın muradının ne olduğu insanlar tarafından anlaşılamaz. ${ }^{42}$

\subsection{Muvâza'a Teorisi}

Muvâza'a sözlükte "biriyle tartışmak", "alışverişten karşılıklı olarak vazgeçmek", "bahse, iddiaya girmek", "iki kişiden her birinin, yekdiğerini kendi görüşüne vâkıf ve muttali kılması" ve "biriyle anlaşıp uzlaşmak" anlamlarına gelmektedir. ${ }^{43}$ Muvâza'a kelimesi, ilmî terimleri ele alan sözlüklerde bir terim olarak geçmemektedir. Onun yerine, aynı anlamda kullanılan "ıstılâh" kavramı bulunmaktadır. Bu kavram "bir lafzın, lûgavî manasının dışında bir mana için, aralarındaki münasebet dolayısıyla kullanılması" veya "bir taifenin, bir lafzı bir mana için vaz' etmesi" ${ }^{44}$ şeklinde tarif edilmektedir. Istılâhın zikredilen ikinci tarifi ile Muvâza'anın sözlük manaları arasında geçen "biriyle anlaşıp uzlaşmak" anlamı arasındaki benzerlik açıktır.

39 Ebû Muhammed Ali b. Ahmed b. Saîd b. Hazm İbn Hazm, el-İhkâm fì usûli'l-ahkâm (Beyrut: Dârü'l-âfâki'l-cedîde, tsz.), 1/29.

40 İbn Hazm, el-ìhkâm fì usûli 'l-ahkâm, 1/130.

41 İbn Hazm, el-ïhkâm fì usûli 'l-ahkâm, 1/130.

42 er-Râzî, el-Mahsûl, 1/187; Sübkî, el-İbhâc fì şerhi'l-minhâc, 3/501.

43 Halil b. Ahmed el-Ferâhîdî, el-Ayn (y.y.: Dâr ve mektebetü'l-hilâl, Tsz.) 1/103; Ebü'l-Fazl Cemâleddîn Muhammed b. Mekrem el-İfrîkî el-Misrî İbn Manzûr, Lisânü'l-Arab (Beyrut: Dâr Sâdır, tsz.) 1/18; Mecme'u'l-Lûga El-Arabiyye, el-Mu'cemü'l-vasît (Mısır: Mektebetü'ş-şurûk eddevliyye, 2004), 1040.

44 Seyyid Şerif Cürcânî, Mu'cemu't-tarifât (Kahire: Dâru'l-Fazile, 2004), 27; Abdürraûf İbnü'lMünâvî, et-Tevkîf alâ mühimmâti 't-teârîf (Kahire: Âlemü'l-kütüb, 1990). 18; Ebü'l-Bekâ Eyyûb b. Musa el-Hüseynî Kefevî, el-Külliyyât (Beyrut: Müessesetü’r-risâle nâşirûn, 1998), 129. 
Muvâza'a yaklaşımının savunuculuğu genelde Mu'tezile, özelde ise Ebu Hâşim'e (ö. 321/933) nispet edilir. 45 İbn Cinnî́ye (ö. 392/1002) göre ehl-i nazarın çoğu dilin aslının muvazaa ve ıstılah olup vahiy veya tevkif olmadığı görüşündedir.

Muvâza'anın nasıl gerçekleştiğine dair farklı açıklamalar mevcuttur. İbn Cinnî'nin Muvâza'a taraftarlarından aktardığg bir açıklamaya göre “İki, üç veya daha fazla bilge kişi toplanır ve bilinen şeyleri anlatma (bilgilerini birbirine aktarma) ihtiyacı duyarlar." Bu bilgeler (hakîm) bir dil vaz' etmenin gereğini fark etmiş ve bu sebeple bir araya gelmişlerdir. Somut ve soyut şeyler için isim koyacaklardır. Bu isimlendirme hem eşyanın birbirinden tefrik edilmesini, hem de hâlihazırda mevcut olmayan şeyler ve duyuların dışında bulunan soyut kavramlar hakkında konuşma imkânı sağlayacaktır. Böylece bu bilgeler eşyaya isim vermek üzere harekete geçerler. İbn Cinnî şu şekilde devam eder: "Bu (bilge) kişiler bir insanın yanına geldiler, ona işaret ettiler ve 'insan' dediler. Artık bu kelime ne zaman işitilse, ondan bu tür bir mahlûkun kastedildiği anlaşıldı. Diğer her şey de bu şekilde isimlendirildi." ${ }^{46}$ (...) "Böylece Muvâza'a yoluyla bir dil oluşturuldu. Bu ilk dilden hareketle daha farklı diller de oluşturuldu. Meselâ 'insan' yerine 'merd', 'baş' yerine 'ser' denildi." 47

Gazâlî de İbn Cinnî'nin açıklamasına benzer bir şekilde Muvâza'ayı açıklar ve şöyle der: "Allah, bazı akıllı insanların, kendileri için ehemmiyet arz eden ve ihtiyaç duydukları şeyler ile meşgul olmak üzere dürtülerini harekete geçirir."48 Tabi dil vaz' etmek için mutlaka birkaç kişinin bir araya gelmesi şart değildir. Bir kişinin de aklına bir dil oluşturmak gerektiği fikri gelebilir. Bu kişi kendince bir kelime üretebilir. Daha sonra bu dili diğer insanlara öğretir. Bunu yaparken de işaret ve tekrarlama yöntemini kullanır. Aslında her insan ana dilini bu yöntemle öğrenmektedir. Dolayısıyla insanların kullandığı ilk dil de bu yöntem kullanılarak öğrenilmiş ve öğretilmiş olabilir. ${ }^{49}$

Muvâza'ayı desteklemek üzere Ebu Hâşim tarafından şöyle bir akıl yürütme yapılmıştır: Eğer dili Allah insanlara talim ve tevkîf etmiş ise; bu iki şekilde olabilir: a) Vahiy yoluyla, b) Kulunda zaruri ilim yaratmak suretiyle. Va-

45 Ebû Reşî̀ en-Nîsâbûrî, el-Mesâil fi'l-hilâf beyne'l-Basriyyîn ve'l-Bağdâdiyyîn (Beyrut: edDirâsâtü'l-insâniyye el-fikrü'l-Arabî, 1979), 158.

46 Ebü'l-Feth Osman İbn Cinnî, el-Hasâis (Kahire: Dârü'l-kütübi’l-Misriyye, 1952), 1/44.

47 es-Suyûtî, el-Müzhir, 1/12.

48 Gazâlî, el-Mustasfâ min ilmi'l-usûl, 3/8; el-Cüveynî, el-Burhân, 1/170.

49 Gazâlî, el-Mustasfâ min ilmi'l-usûl, 3/9. 
hiy şeklinde talim olamaz. Zira ayette "Biz her resulü kendi kavminin lisanıyla gönderdik..." (İbrahim: 14/4) denilmektedir. Resulün kendi kavminin diliyle gönderilmesi demek, dilin onlara resul tarafından öğretilmediğini, kavmin o dili zaten bildiğini ve resulün de bildikleri dil ile o kavme hitap ettiğini gösteriyor. Dolayısıyla Ebu Haşim'in ifadesiyle “dil, peygamber gönderilmeden önce vardır." İkinci ihtimal, yani kulda Allah'ın zaruri ilim yaratması yoluyla da talim olamaz. Zira bu durumda kul Allah'ın bu lafzı, bu manaya karşılık vaz'ettiğini bilir ve dolayısıyla Allah'ı da zarureten bilir. Hâlbuki kul mükelleftir ve Allah'ı zarureten bilmek, teklifi ortadan kaldırır. ${ }^{50}$

Böylece Ebu Hâşim dilin kaynağının vahiy veya zorunlu bilgi olma seçeneklerini eleyerek muvazaanın esas kaynak olduğunu ortaya koymaya çalışır. Ebu Hâşim'in, görüşünü temellendirirken özellikle sorumluluk meselesini öne çıkarttığı görülmektedir. Bu durumda dil Allah tarafından öğretilmiş bir olgu olsaydı, bu dilin anlamına zorunlu olarak işaret eder, böylece Allah inancı başta olmak üzere insan sorumluluklarını zorunlu olarak bilmesi gerekirdi. Oysa insan önce bilmediklerini öğrenmek ve öğrendiklerini hayat geçirmekle mükellef tutulmuştur.

\subsection{Tevakkuf Teorisi}

Sözlükte durmak anlamına gelen ${ }^{51}$ bu kelime, bir konuda delillerin çatışması durumunda tercihi terk etme ${ }^{52}$ anlaminda bir Fikıh Usûlü terimi olarak kullanılmaktadır. Bu kavram, dillerin kökenine dair Usûl kitaplarında yapılan tartışmalarda kullanılmış ve muhakkiklerin genel yaklaşımı olarak aktarılmıştır. Ancak bu yaklaşım Eş'arîlere veya ehl-i sünnete özgü bir yaklaşım değildir. Meselâ İbn Cinnî, dilin kökeni hakkında farklı görüşleri nakledip kendi yaklaşımını aktarırken, bu konuyu "sürekli düşünüp incelediğini", farklı görüşler arasında gidip geldiğini, "bu şerefli, keremli, latif dilin (Arapça) içerdiği hikmet, incelik, duyarllık ve rikkati" ve "bu konuda tevkîfe dair rivayet edilen haberleri" göz önünde bulundurduğunda, dilin "Allah'ın öğretmesi ve vahiy" olduğuna dair içindeki inancın güçlendiğini ifade eder. Dolayısıyla, İbn Cinnî böyle bir dilin biz insanlar tarafından yaratılmış olmasını uzak bir ihtimal olarak görür.

50 Sübkî, el-İbhâc fì şerhi'l-minhâc, 3/507-508; Tâcüddîn Abdülvehhâb b. Ali b. Abdülkâfî es-Sübkî, Ref'u'l-hâcib an muhtasari İbni'l-Hâcib, thk. Ali Muhammed Muavvad, Adil Ahmed Abdülmevcud (Beyrut: Âlemü'l-Kütüb, ts.), 1/443.

51 Kadir Güneş, Arapça-Türkçe Sözlük (İstanbul: Mektep Yayınları, 2011), 1322, 45.

52 Mahmûd Hâmid Osman, el-Kâmûsü'l-mübîn fî̀ ıstılâhati'l-usûliyyîn (Riyad: Dârü’z-zâhim, 2002), 117; Kefevî, el-Külliyyât, 304. 
Ancak, Allah tarafından, bizden çok uzun zaman önce yaratılmış, bizden daha kapasiteli varlıkların bulunabileceği, böyle bir dili onların vücuda getirmiş olabileceği ihtimalini de dile getirir ve bu durum karşısında kararsız kaldığını ifade eder. ${ }^{53}$ Yine her ikisi de dil ilimlerinde imam mertebesinde bulunan Mutezilî bilginler Ebü'l-Hasen el-Ahfeş (ö. 218/830) ve Ebu Ali el-Fârisî (ö. 377/987) ile ilgili nakillerinde ${ }^{54}$ de bu zatların tevakkuf ettiklerini veya kararsız kaldıklarını görüyoruz. Bunun dışında Ebu Ali el-Cübbâî'nin de tevkîf ve Muvâza'ayı caiz gördüğü nakledilmektedir. ${ }^{55} \mathrm{Bu}$ nakillerden hareketle Mutezile içinde de tevakkuf yaklaşımını benimseyen veya kararsız kalanların bulunduğunu söyleyebiliriz.

Eş'arîlerde tevakkuf yaklaşımı özellikle Kâdî Ebû Bekir el-Bâkıllânî (ö. 403/1013) ve sonrasında görülmektedir. O, dillerin kökenine dair farklı görüşleri madde madde sıralar ve şöyle der: "Bu görüşlerin hepsinin mümkün olduğunu içeren son görüş, bizim de seçimimiz ve hükmümüzdür." 56 İmâmü'lHarameyn el-Cüveynî (ö. 478/1085) de tevkîf ve uzlaşmayı (Muvâza'a) aynı şekilde caiz görür. Cüveynî tevkîfin imkânını "Allah'ın göğüslerde yaratacağı bedîhî ilim" ile açıklarken, Muvâza'anın imkânını "Allah akıl sahiplerinin nefislerini bu iş (isim vaz'etme) için harekete geçirir ve insanlar birbirlerine meramlarını iletirler. Böylelikle dilin kalıpları insanların gayretleriyle oluşur" ${ }^{\prime \prime}$ şeklinde izah eder. Gazâlî (ö. 505/1111) konuyla ilgili kendi görüşünü açıklarken, meseleyi "cevaz ve vuku açısından" ele alır ve aklen Muvâza'a ve tevkîf görüşlerinin aynı şekilde caiz ve mümkün olduğunu belirtir. ${ }^{58}$ Ancak bu görüşlerden hangisinin gerçekte vuku bulduğunu bilmenin bir imkânı olmadığını da ekler. Çünkü der, "bunu kesin olarak bilmek için ya aklî burhan, ya mütevâtir haber, ya da sem'i-kâtı'/kesin naklî delil olması gerekir. Bu konuda aklî delile imkân yoktur. Tevâtür nakledilmemiştir. Kesin naklî delil de yoktur." 59 Fahreddin Râzî de (ö. 606/1210) dilin kökeniyle alakalı tüm görüşleri aktarır ve "muhak-

53 İbn Cinnî, el-Hasâis, 1/47.

54 İbn Cinnî, el-Hasâis, 1/40-41.

55 en-Nîsâbûrî, el-Mesâil fi'l-hilâf, 158.

56 Kâdî Ebû Bekir Muhammed b. Tayyib el-Bâkıllânî, et-Takrîb ve'l-irşâd (es-Sağîr) (Beyrut: Müessesetü’r-risâle nâşirûn, 1998), 1/319-320; es-Suyûtî, el-Müzhir, 1/120.

57 el-Cüveynî, el-Burhân, 1/170.

58 Gazâlî, el-Mustasfâ min ilmi' l-usûl, $3 / 8$.

59 Ebû Hâmid Muhammed b. Muhammed b. Muhammed b. Ahmed el-Gazâlî, el-Mustasfâ min ilmi'lusûl (Medine: Şirketü'l-Medîneti'l-Münevvere li't-tıbâa, tsz.), 3/9. 
kikler, Abbâd b. Süleyman'ın görüşü hariç (bunların) hepsinde tevakkuf ederler"60 der.

Görüldüğü üzere Bâkıllânî ile başlayan ve devam eden Eş'arî çizgi genellikle tevakkuf yaklaşımını benimsemektedir. Ancak Râzî sonrası dönemde fark11 bir yaklaşım daha görmekteyiz. Özellikle Âmidî61 (ö. 631/1233), İbn Hâcib (ö. 646/1249) ve İbn Dakîku'l-Îd (ö. 702/1302) gibi müteahhir ulemanın benimsediği bu yaklaşıma göre, Eş'arî'nin görüşü kesinlik ifade etmemekle birlikte tercihe şayandır. Âmidi'ye göre, eğer dilin kökeninin nasıl vuku bulduğuna dair bir kesinlik (yakînü'l-vukû) aranırsa, Bâkıllânî haklıdır. Çünkü nasıl vuku bulduğu yakînen bilinmemektedir. Fakat maksat vuku ile ilgili zannî bir bilgiye sahip olmaksa -ki aranması gereken budur- bu durumda Eş'arî haklıdır. Zira nasların zâhiri bunu göstermektedir. ${ }^{62}$ İbn Hâcib de Eş'arî'nin kavlinin "zâhir"63 olduğunu söylemektedir. ${ }^{6465}$ Tâceddin es-Sübkî (ö. 771/1370) İbn Hâcib'in bu görüşünü şöyle açıklar: “İbn Hâcib'in sözünün manası şudur: 'Íhtimallerden herhangi birisi hakkında kesin bir hüküm vermekten kaçınmak ve zann-1 galip ile Eş'arî'nin görüşünü tercih etmek." ${ }^{66}$

Böylece Eş'arî ile başlayan ve dilin kesin olarak tevkîfîliğinini ${ }^{67}$ savunan Eş'arî çizgi, Bâkıllânî ile birlikte tevakkufa evrilmiş daha sonra Âmidî ile birlikte yeni bir yaklaşımla tekrar Eş'arî'nin görüşüne dönülmüştür.

60 er-Râzî, el-Mahsûl, 1/182.

61 Weis, "bu görüşün bildiğim tek savunucusu Seyfeddîn el-Âmidî’dir” der. (Weiss, “Ortaçağ İslâm Âlimlerinin Dilin Menşei ile İlgili Tartışmaları”, 129.) Ancak Suyûtî’nin nakline göre bu görüş müteahhir âlimlerin görüşüdür. es-Suyûtî, el-Müzhir, 23-24.

62 Ali b. Muhammed el-Âmidî, el-İhkâm fî usûli’l-ahkâm, (Riyad: Dârü’s-Samî’î, 2003), 1/103.

63 Zâhir kavramı Usûlü'l-fıkh kitaplarında şöyle tanımlanır: "Manasının anlaşılması için harici bir karîneye ihtiyaç duyurmayacak şekilde bu manaya açık olarak delâlet eden, fakat tevil ve tahsis ihtimaline açık bulunan (...) lafızdır." Bkz. Zekiyyüddin Şaban, İslâm Hukuk İlminin Esaslarl (Usûlü'l-Fıkh), çev. İbrahim Kâfi Dönmez (Ankara: Türkiye Diyanet Vakfı Yay., 2000), 369.

64 İbn Hâcib, Muhtasar, 1/171.

65 İbn Hâcib, Muhtasar, 1/171.

66 Sübkî, el-İbhâc fî şerhi'l-minhâc, 3/504-506.

67 Kaynaklarda, Eş’arînin tevkîf görüşünü nasıl savunduğu konusunda birtakım şüpheler vardır. Meselâ Bâkıllânî, Cüveynî ve Gazâlî tevkîf görüşünü Eş’arî’ye nispet etmemektedir. Râzî ve Zerkeşî ise tevkîf görüşünü Eş’arî ve İbn Fûrek'e nispet eder. Sübkî ise bu görüşü sadece İbn Fûrek'e isnad eder, Eş'arî'ye isnâdını ise zayıf bulur. Bkz. İbn Hâcib, Muhtasar müntehâ es-su'l ve 'l-emel fî ilmeyi'l-usûl ve'l-cedel, 1/269 Yine Sübkî “'tevakkufun muhakkiklerin görüşü olduğunu, Eş'arî'den de bunun hilâfına bir şeyin nakledilmediğini" söyler ve "Bana göre Eş’arî vuku hakkında konuşmuştur ve dillerin 1stılâhen meydana gelmesini (o da) caiz görmektedir. Şayet cevâzı menetseydi bunu Bâkıllânî ve Eş’arî kelâmının diğer muhakkikleri naklederlerdi. Hâlbuki bunu naklettiklerini görme- 


\section{DİLLERINN KÖKENINE İLISŞKİN YAKLAŞIMLARIN TEOLOJIKK BAĞLAMI}

Lafız ve mana arasında zorunlu bir ilişkinin olduğunu savunan Süleyman b. Abbâd'ın zâtî delâlet teorisi ve kararsızlığı ifade eden tevakkuf görüşünü bir tarafa bırakırsak dillerin kökeni hakkındaki yaklaşımları ikiye indirgeyebiliriz. Birincisi Eş'arî âlimlerinin çoğunluğu tarafından savunulan dillerinin kökeninin Allah'ın öğretmesine dayandığını savunan tevkîfî yaklaşım diğeri de Mutezile'nin savunduğu dillerin kökenini insanların uzlaşmasına dayandıran Muvâza'a yaklaşımıdır. Kelam ekollerinin dillerin kökenine ilişkin bu görüşleriyle kelam anlayışları arasında bir ilişki bulunduğu söylenebilir.

İlk olarak dillerin kökenine ilişkin tartışmanın Allah'ın isimleri konusuyla alakası bulunduğu görülmektedir. Dillerin kökenini insanların uzlaşmasına dayandıran $\mathrm{Mu}$ 'tezile, şerî bir bildirim veya izin olmadan yüce Allah'a layık isim ve sıfatların verilebileceğini söyler ${ }^{68}$ Çünkü onlara göre dilin menşei, içinde yaşadığımız evrendir. Buna göre lafızların manaları önce bu âlemde belirlenir sonra gaip alana uygulanır. ${ }^{69}$ Dolayısıyla dilin kökenini insanlar arasındaki uzlaşmaya dayandırmak, Allah'a onun layık olduğu isimleri vermenin yolunu açan bir anlayış olarak karşımıza çıkmaktadır. Dilin kaynağını Allah'ın öğretimine dayandıran Ehl-i sünnet âlimleri ise şeriatın belirlediği isimlerin dışında Allah'a kıyas yoluyla isim vermeyi caiz görmemişlerdir. Ancak Gazâlî ile Râzî tarafından benimsenen tercihe göre bu noktada "isim" ile "vasıf" birbirinden ayrı düşünülmelidir. Nasla sabit olmayan bir ismi Allah'a nisbet etmenin meşrû olmadığı; bununla birlikte ulûhiyyete ters düşmeyen bir kavramla O'nu nitelendirmenin mümkün olduğu belirtilmiştir.70 Dolayısıyla bütün isimlerin Âdem'e öğretildiği beyanına dayandırılan dilin tevkîfîliği görüşü ile nasların dışında geçen isimlerin Allah hakkında kullanılmasının mümkün olmadığı görüşü arasında yakın bir alaka olduğu görülmektedir.

dim. Hatta Bâkıllânî, Cüveynî ve İbnü'l-Kuşeyrî, dillerin kökeni konusunda Şeyh’ten (Eş’arî) hiç bahsetmemektedirler" der. Sübkî, Ref'u'l-Hâcib, 1/444. Ancak Eş'arî'nin eserlerinde bu konu geçmemekle beraber, İbn Fûrek tevkîf görüşünü açıcça Eş'arî'ye nispet eder. İbn Fûrek, Mücerred, 42.

68 Kâdî Abdülcebbâr, Ebü'l-Hasen Abdülcebbâr b. Ahmed b. Abdilcebbâr el-Hemedânî, el-Muğnî (Kahire: el-Müessesetü'l-Misriyyetü'l-Âmme, 1957), 5/174.

69 Kâdî Abdülcebbâr, el-Muğnî, 5/188.

70 Bekir Topaloğlu, “Allah”, Türkiye Diyanet Vakfi İslam Ansiklopedisi (Türkiye Diyanet Vakfı Yayınları, 1989), 2/483. 
İkinci olarak dillerin kökeni meselesinin teklif konusuyla alakalı olduğu görülmektedir. Ebû Hâşim'in Muvâza'a teorisini benimseyen Mutezile uleması insanın teklife muhatap olabilmesi için bir dile sahip olması gerektiğini bu yüzden de dilin kökeninin tevkîfî olamayacağını söylemişlerdir. Kâdî, "Allah'ın, muradını hitabından anlayabileceğimiz şekilde bize hitap edebilmesi, ancak bizim bazı diller üzerinde Muvâza'a etmemizden sonra sahih olabilir"71 der.

Üçüncü olarak dillerin kökeni hakkında kelam ekollerinin yaklaşımları Kur'an'ın tevil edilmesine yönelik görüşleriyle de ilişkilidir. Çünkü dilin kökenini insanlar arası uzlaşıya dayalı olarak sonradan meydana gelen bir olgu olduğunu, ilahi kelamın da konuşulan bu sözlerin kalıbıyla sonradan meydana geldiğini söylemek, Kur'an'ı te'vil etmenin yolunu açan bir görüş olmaktadır. Bir şey, yaratılmış ise o şeye dokunulabilir, yaklaşılabilir ve anlaşılabilir. Tam aksine ilahi kelamın ezeli olduğunu söylemek bir noktada onun dokunulmaz ve tevil edilemez veya sınırlı bir şekilde te'vili mümkün bir söz gibi algılanmasına sebep olacaktır. Nitekim ehl-i sünnet-i hâssa olarak da bilinen selef uleması te'vîle olumsuz yaklaşmış, ehl-i sünnet kelamcılarının mana ve lafız olan kelamı birbirinden ayırdıktan sonra te'vile daha olumlu tavır sergilemiştir.

\section{SONUÇ}

Çalışmamız sırasında tespit ettiğimiz noktalardan biri, dillerin kökenini Allah'a dayandıranların (tevkîf) Eşarîler, insanların uzlaşmasına (Muvâza'a) dayandıranların ise Mutezile olduğu yönündeki kanaatlerin, ilgili mezheplerin genel görüşleri olmadığı yönündedir. Çünkü Mutezile içinde tevkîf, tevakkuf ve Muvâza'a yaklaşımlarını benimseyenler olduğu gibi, Eş'arîler içinde de tevkîf ve Muvâza'ayı mümkün görenler bulunmaktadır. Dolayısıyla, Eş'arîlerin tamamı tevkîf görüşünü benimsemediği gibi, Muvâza'a yaklaşımı da Mu'tezile ile özdeşleşmiş bir yaklaşım sayılmamalıdır. Bununla birlikte Mu'tezile'nin önemli kelâmcılarının bu görüşü savunması, bu hususta Muvâza'a görüşünün Mu'tezile ile birlikte anılmasına sebep olmuştur.

Muvâza'a yaklaşımı Mu'tezile içinde Ebû Hâş̧im ve takipçileri tarafından savunulmuştur. Mu'tezile'nin Bağdat ekolü ve Ebû Hâşim öncesi Basra kelâmcıları ise, bu konuda farklı görüşler ortaya koymuşlardır. Eş'ariyye'nin yaklaşımları zaman içinde değişmiş ve müteahhir Eş'arî kelâm ve usûlcüleri için ilk

71 Kâdî Abdülcebbâr, el-Muğnî, 5/163. 
dilin ne olduğu sorusu önemini kaybetmiştir. Bu konuda daha önce ortaya at1lan görüşleri aktaran ve bu görüşlerden hepsinin mümkün olduğunu söylemekle yetinen bu bilginler, dilin kökeni konusunu araştırmanın gereksiz ve yararsız olduğu kanaatine ulaşmışlardır.

Dillerin kökenine ilişkin teorilerin birtakım teolojik bağlamlara sahip olduğu görülmektedir. Konunun özellikle Allah'a isim verme meselesiyle yakından alakalı olduğu görülmektedir. Kelamcıların dillerin kökeniyle ilgilenmesi ilk önce Allah'a isim ve sıfat verme hakkındaki problemlere yöneliktir. Dilin kökenini insanların uzlaşmasına dayandıran Mu’tezile âlimleri kıyas yoluyla akıl tarafından Allah'a layık isimleri vermenin doğruluğunu savunurken, dillerin kökenini Allah'ın öğretmesine dayandıranlar bilhassa Allah'ın isimlerinin ancak vahiyle belirlenebileceğini ileri sürmüşlerdir. Dillerin kökeni hakkındaki teoriler, teklif ve tevîl konusuyla da ilişkilendirilmiştir. Allah'ın insan cinsine teklifte bulunabilmesi için, önceden insanlar arasında konuşulan bir dile gereksinim olduğundan hareketle Mu'tezile dilin kökeninin beşeri alana ait olduğunu savunmuştur. Onlar, dilin Allah tarafından öğretilmesinin Allah'ı zorunlu olarak bilmeyi gerektireceğini, bunun da teklifin mantığıyla bağdaşmayacağını savunmuşlardır. Bunun yanında Muvâza'a görüşünün Kur'an'ın te'vîli ve Allah'ı isimlendirme konusunda kendi teolojik sistemlerine uygun düşecek biçimde $M u^{\prime}$ tezile'ye bir hareket alanı sağladığı görülmektedir.

\section{KAYNAKÇA}

Altınörs, S. Atakan. “Rousseau'nun Dilin Kökeni Meselesine Yaklaşımı”. Bilig Türk Dünyası Sosyal Bilimler Dergisi 4/63 (2012), 1-10.

Âmidî, Ali b. Muhammed el-. el-İhkâm fî Usûli'l-Ahkâm. Riyad: Dâru's-Samîı', 2003.

Âmidî, Seyfüddîn el-. el-İhkâm fî̀ uṣ̂uli'l-aḥkâm. Beyrut, ts.

Aydar, Hidayet - Ulutaş, İsmail. “Kur'an-1 Kerim Ve Diğer Kutsal Kitaplara Göre Dil Olgusu". Turkish Studies 5/4 (2010), 679-696.

Bâkıllânî, Kâdî Ebû Bekir Muhammed b. Tayyib el-. et-Takrîb ve'l-irşâd (es-Să̆ĝ̀r). Beyrut: : Müessesetü'r-risâle nâşirûn, 2. Baskı., 1998.

Bozgöz, Faruk. "Dil-Toplum İlişkisi ve Ari-Sami Polemiğinde Dil ve Sami Dilleri”. Ekev Akademi Dergisi Yaz/20 (2004), 277-294.

Câbirî, Muhammed Âbid el-. Binyetü'l-akli'l-Arabî. Beyrut: Merkez dirâsât el-vahde elArabiyye, (9. Baskı)., 2009.

Cürcânî, Seyyid Şerif. Mu'cemu't-tarifât. Kahire: Dâru'l-Fazile, 2004. 
Cüveynî, İmâmü'l-Haremeyn Ebü'l-Meâlî Abdülmelik b. Abdullah b. Yusuf el-. elBurhân fì usûli'l-fikh. Katar: Şeyh Halîfe b. Hamad Âl-Sânî, 1. Baskı., 1978.

Dessalles, Jean-Louis - v.dğr. Dilin Kökenleri. çev. S. Atakan Altınörs. İstanbul: Bilge Kültür Sanat Yayınları, 1. Basım., 2014.

Ebû Zeyd, Nasr Hâmid. el-İtticâh el-aklî fi't-tefsîr: Dirâse fî̀ kaziyye el-mecâz fi'l-Kur'ân inde'lMu'tezile. Beyrut: el-Merkez es-sekâfî el-Arabî, 3. Baskı., 1996.

Ferâhîdî, Halil b. Ahmed el-. el-Ayn. Y.y.: Dâr ve mektebetü'l-hilâl, Tsz.

Gazâlî, Ebû Hâmid Muhammed b. Muhammed b. Muhammed b. Ahmed. el-Mustasfâ min ilmi'l-usûl. IV Cilt. Medine: Şirketü'l-Medîneti'l-Münevvere li't-tıbâa, tsz.

Güneş, Kadir. Arapça-Türkçe Sözlük. İstanbul: Mektep Yayınları, 2011.

İbn Berhân, Şerefü'l-İslâm Ebü'l-Feth Ahmed b. Ali b. Berhân el-Bağdâdî. el-Vusûl ile'lusûl. Riyad: Mektebetü'l-meârif, 1983.

İbn Cinnî, Ebü'l-Feth Osman. el-Hasâis. III Cilt. Kahire: Dârü'l-kütübi'l-Misriyye, (2. Bask1)., 1952.

İbn Fâris, Ebü'l-Hüseyn Ahmed b. Fâris b. Zekeriyya. es-Sâhibî fî fikhi'l-lûgati'l-Arabiyyeti ve mesâilihâ ve süneni'l-Arabi fî kelâmihâ. Beyrut: Dârü'l-kütübi'l-ilmiyye, (1. Bask1)., 1997.

İbn Fûrek. Mücerredü Makâlâti'ş-Şeyh Ebi'l-Hasan el-Eş'arî. Beyrut: Dâru'l-Meşrik, 1987.

İbn Hâcib, Cemâleddîn Ebû Amr Osman b. Ömer b. Ebû Bekir. Muhtasar müntehâ es-su'l ve'l-emel fî ilmeyi'l-usûl ve'l-cedel. II Cilt. Beyrut: Dâr İbn Hazm, (1. Bask1)., 2006.

İbn Hazm, Ebû Muhammed Ali b. Ahmed b. Saîd b. Hazm. el-İhkâm fì usûli'l-ahkâm. Beyrut: Dârü'l-âfâki'l-cedîde, tsz.

İbn Manzûr, Ebü'l-Fazl Cemâleddîn Muhammed b. Mekrem el-İfrîkî el-Misrî. Lisânü'lArab. Beyrut: Dâr Sâdır, 1. Baskı., tsz.

İbn Teymiyye, Ahmed b. Abdülhalîm el-Harrânî. Mecmû'u fetâvâ Şeyhülislâm İbn Teymiyye. Medine: Mucemme'u'l-melik Fehd, 2004.

İbnü'l-Münâvî, Abdürraûf. et-Tevkîf alâ mühimmâti't-teârîf. Kahire: Âlemü'l-kütüb, (1. Bask1)., 1990.

Kâdî Abdülcebbâr, Ebü'l-Hasen Abdülcebbâr b. Ahmed b. Abdilcebbâr el-Hemedânî. elMuğnî. Kahire: el-Müessesetü'l-Mısriyyetü'l-Âmme, 1957.

Kefevî, Ebü'l-Bekâ Eyyûb b. Musa el-Hüseynî. el-Külliyyât. Beyrut: Müessesetü'r-risâle nâşirûn, (2. Baskı)., 1998.

Koloğlu, Orhan Şener. Cübbâîler'in Kelâm Sistemi. İstanbul: TDV İSAM Yayınları, 2011.

Mahmûd Hâmid Osman. el-Kâmûsü'l-mübîn fî ıstılâhati'l-usûliyyîn. Riyad: Dârü'z-zâhim, (1. Bask1)., 2002.

Mecme'u'l-lûga el-Arabiyye. el-Mu'cemü'l-vasît. Mısır: Mektebetü'ş-şurûk ed-devliyye, (4. Bask1)., 2004. 
Mecme'u'l-Lûga El-Arabiyye. el-Mu'cemü'l-vasît. Misır: Mektebetü'ş-şurûk ed-devliyye, 2004.

Nîsâbûrî, Ebû Reşîd en-. el-Mesâil fi'l-hilâf beyne'l-Basriyyîn ve'l-Bă̆gâdiyyîn. Beyrut: edDirâsâtü'l-insâniyye el-fikrü'l-Arabî, 1. Baskı., 1979.

Pezdevî, Ebü'l-Yüsr Muhammed el-. Usûlü'd-dîn. thk. Hans Peter Linss. Kahire: elMektebetü'l-Ezheriyye li't-Türâs, 2003.

Platon. Kratylos" Diyaloglar I. çev. Teoman Aktürel. İstanbul: Remzi Kitabevi, 1983.

Râzî, Fahreddîn Muhammed b. Ömer b. el-Hüseyn er-. el-Mahsûl fî ilmi usûli'l-fikh. Y.y.: Müessesetü'r-risâle nâşirûn, tsz.

Sübkî, Tâcüddîn Abdülvehhâb b. Ali b. Abdülkâfî. Ref'u'l-hâcib an muhtasari İbni'l-Hâcib. thk. Ali Muhammed Muavvad, Adil Ahmed Abdülmevcud. 4 Cilt. Beyrut: Âlemü'l-Kütüb, ts.

Sübkî, Tâcüddîn Abdülvehhâb b. Ali b. Abdülkâfî. el-İbhâc fî şerhi'l-minhâc. 6 Cilt. Dubai: Dârü'l-buhûs li'd-dirâsati'l-islâmiyye, (1. Baskı)., 2004.

Suyûtî, Celâleddîn. el-Müzhir fî ulûmi'l-lûga ve envấihâ. Beyrut: Menşûrâtü'l-mektebeti'lasriyye, 1986.

Suyûtî, Celâleddin. el-Müzhir. Kahire: Dâru ihyâi'l-kütübi'l-Arabiyye, tsz.

Topaloğlu, Bekir. "Allah”. Türkiye Diyanet Vakfı İslam Ansiklopedisi. II/471-498. Türkiye Diyanet Vakfı Yayınları, 1989.

Weiss, Bernard G. “Ortaçă̆ İslâm Âlimlerinin Dilin Menşei ile İlgili Tartışmaları”. çev. Adem Yığıın 2/25 (2003), 127-135.

Yıldırım, Zeki. "Kur'ân Işığında Dillerin kaynağı Problemi”. Atatürk Üniversitesi İlâhiyat Fakültesi Dergisi 22 (2004), 88-107.

Yücel, Muhammet. “Erken Dönem Sasanilerde Kadın Ve Hanedan”. Tarih Dergisi / Turkish Journal of History 61 (ts.), 25-56.

Zekiyyüddin Şaban. İslâm Hukuk İlminin Esasları (Usûlü'l-Fıkh). çev. İbrahim Kâfi Dönmez. Ankara: Türkiye Diyanet Vakfı Yay., (4. Baskı)., 2000. 